\title{
Hubungan antara tingkat pendidikan ibu dan kedisiplinan terhadap prestasi belajar IPS di Kota Mungkid, Kabupaten Magelang
}

oleh:

\author{
Ina Arifa \\ Universitas Negeri Yogyakarta \\ ina.arifa2016@student.uny.ac.id \\ Sudrajat \\ Universitas Negeri Yogyakarta \\ sudrajat@uny.ac.id
}

\begin{abstract}
Abstrak
Tingkat pendidikan orang tua yang baik mampu membimbing dan mengarahkan puteranya dalam mengikuti kegiatan belajar di sekolah. Tujuan penelitian untuk mengetahui (1) hubungan tingkat pendidikan ibu dengan prestasi belajar IPS peserta didik SMP di Kota Mungkid, Magelang; (2) hubungan antara kedisiplinan belajar dengan prestasi belajar IPS; (3) hubungan tingkat pendidikan ibu dan kedisiplinan belajar terhadap prestasi belajar IPS. Penelitian menggunakan metode penelitian kuantitatif jenis korelasional. Sampel penelitian siswa kelas VII dan VIII SMP Negeri 1 Kota Mungkid sebanyak 182 orang. Teknik pengumpulan data menggunakan kuesioner dan dokumentasi. Hasil penelitian menunjukkan bahwa: (1) terdapat hubungan positif dan signifikan antara tingkat pendidikan ibu dengan prestasi belajar IPS ( $\mathrm{r}_{\text {hitung: }} 0,458>\mathrm{r}_{\text {tabel }}$ : 0,148); (2) terdapat hubungan positif dan signifikan antara disiplin belajar siswa dengan prestasi belajar IPS ( $\mathrm{r}_{\text {hitung: }}$ 0,383 $>\mathrm{r}_{\text {tabel }}: 0,148$ ); (3) terdapat hubungan positif dan signifikan secara bersama-sama tingakat pendidikan ibu dan disiplin belajar siswa terhadap prestasi belajar IPS ( $F_{\text {hitung: }}$ 24,796 $>F_{\text {tabel: }}$ 3,05).

Kata kunci: tingkat pendidikan, disiplin belajar, prestasi belajar IPS, Kota Mungkid
\end{abstract}

\begin{abstract}
A good level of parental education proficient able to guide and control their sons in participating in learning activities at school. This research aims to determine (1) the relationship between the level of maternal education and the social studies learning achievement of junior high school students in Mungkid City, Magelang; (2) the relationship between learning discipline and social studies learning achievement; (3) the relationship between mother's education level and learning discipline on social studies learning achievement. This research uses correlational quantitative research methods. The sample of the research was 182 grade students of SMP Negeri 1 Mungkid City. Data collection techniques using questionnaires and documentation. The results of this study indicate that: (1) there is a positive and significant relationship between maternal education level and social studies learning achievement (rcount: $0.458>$ rtable: 0.148 ); (2) there is a positive and significant relationship between student learning discipline and social studies learning achievement (rcount: $0.383>$ rtable: o.148); (3) there is a positive and significant relationship together with the level of maternal education and student learning discipline on social studies learning achievement (Fcount: 24.796> Ftable: 3.05).

Keywords: education level, learning discipline, social studies learning achievement, Mungkid City
\end{abstract}


Hubungan antara tingkat pendidikan ibu ... (Ina Arifa \& Sudrajat)

\section{Pendahuluan}

Memasuki abad XXI bangsa Indonesia menghadapi permasalahan yang amat krusial dalam kehidupan berbangsa dan bernegara. Seiring dengan berkembangnya globalisasi, bangsa Indonesia memasuki sebuah zaman dimana keterbukaan, liberalisasi, dan komersialisasi menjadi arus utama yang harus diikuti untuk dapat eksis dalam percaturan kehidupan global. Era globalisasi yang sedang berjalan dan bergulir di dalam kehidupan, mengingatkan kita pada Toffler (1982) yang menyatakan bahwa dunia sedang memasuki peradaban gelombang ke tiga, yaitu peradaban pasca industri yang ditandai dengan kemajuan yang sangat pesat dalam teknologi informasi, yang sudah menjadi salah satu ciri utama arus globalisasi.

Hoessein (2000) mendefinisikan globalisasi dapat dipandang sebagai proses penyesuaian terhadap kondisi internasional dan penciptaan berbagai penyesuaian terhadap kondisi internasional dan penciptaan berbagai kemungkinan melalui interaksi para pelaku dalam bidang sosial, budaya ekonomi, politik dan dimensi teknologi menjadi suatu intensifikasi interaksi kebudayaan sosial, ekonomi dan saling ketergantungan antar negara, individu, dan rakyat. Dalam kondisi yang demikian suatu negara tidak dimungkinkan hidup secara mandiri, akan tetapi harus berhubungan dengan negara lain dalam rangka memenuhi kebutuhan dan mengatasai keterbatasannya. Untuk dapat tetap eksis dan berkiprah dalam dunia internasional serta menjadi bangsa yang kompetitif, mutlak diperlukan sumber daya manusia yang unggul.

Dimyati dan Mujiono (2013) menyatakan sumber daya manusia yang berkualitas merupakan modal dasar pembangunan nasional yang memiliki potensi besar untuk mencapai kesuksesan pembangunan. Semakin tinggi kualitas manusia potensi suatu negara untuk berkembang menjadi negara maju akan semakin besar. Kualitas sumber daya manusia yang tinggi ditunjukkan dengan penguasaan ilmu, pengetahuan, dan teknologi, yang dapat dicapai melalui pendidikan. Oleh karenanya, pemerintah berusaha sekuat tenaga meningkatkan kualitas manusia Indonesia melalui penyediaan layanan pendidikan yang baik. UndangUndang Nomor 20 Tahun 2003 tentang Sistem Pendidikan Nasional, menyatakan bahwa tujuan pendidikan nasional adalah mengembangkan potensi peserta didik agar menjadi manusia yang beriman dan bertakwa kepada Tuhan Yang Maha Esa, berakhlak mulia, sehat, berilmu, cakap, kreatif, mandiri, dan menjadi warga negara yang demokratis serta bertanggung jawab (Supardi dan Widiastuti, 2014: 145).

Pendidikan formal merupakan salah satu wujud nyata implementasi Undang-Undang Nomor 20 Tahun 2003 yang bertujuan mencerdaskan kehidupan bangsa. Saliman (2015) menyatakan bahwa pendidikan formal merupakan pendidikan di sekolah yang dapat menyiapkan siswa agar mampu berperan aktif dan positif dalam kehidupanya saat ini maupun yang akan datang. Pendidikan di sekolah juga dapat menghasilkan sumber daya manusia yang 
berkualitas, serta mencetak lulusan yang mampu mengamalkan ilmu dan keterampilan yang telah diperoleh selama di sekolah (Supardi dan Widiastuti, 2014).

Shobri (2017) menyebutkan bahwa salah satu usaha untuk meningkatkan mutu pendidikan adalah meningkatkan prestasi akademik siswa. Usaha untuk meningkatkan mutu pendidikan dapat menggunakan penilaian prestasi belajar siswa sebagai indikator langsung terhadap kualitas pendidikan, sehingga perlu untuk meningkatkan prestasi belajar. Djamaroh (2002: 231) menyatakan bahwa prestasi adalah hasil kegiatan usaha belajar yang dinyatakan dalam bentuk, angka, huruf, maupun kalimat yang dapat mencerminkan hasil yang telah dicapai oleh setiap siswa. Prestasi belajar siswa dapat dilihat dari nilai rapor siswa. Pada umumnya pendidikan di sekolah dilaksanakan secara umum, dimana siswa pada tingkat yang sama mendapatkan materi yang sama, pengajaran yang sama, ruang yang sama, dan fasilitas yang sama pula (Shobri, 2017). Hal tersebut tidak sebanding dengan prestasi yang dicapai siswa dalam satu kelas karena capaian prestasi setiap siswa berbeda, ada siswa yang mendapatkan prestasi baik, namun ada pula siswa yang mendapatkan prestasi belajar kurang baik.

Dalam pandangan Syafii, dkk. (2018) prestasi belajar merupakan hasil belajar yang dicapai setelah melalui proses kegiatan belajar mengajar. Prestasi belajar dapat ditunjukkan melalui nilai yang diberikan oleh seorang guru dari jumlah bidang studi yang telah dipelajari oleh peserta didik. Setiap kegiatan pembelajaran tentunya selalu mengharapkan akan menghasilkan prestasi belajar yang maksimal yang ditunjukkan dengan nilai hasil belajar yang tuntas sesuai dengan kriteria yang ditentukan. Namun disamping penilaian aspek pengetahuan yang perlu diperhatikan adalah aspek afektif dan psikomotor yang akan menunjang kompetensi peserta didik dalam memecahkan persoalan-persoalan yang ditemui di lingkungan masing-masing. Namun dalam mencapai prestasi belajar tentunya mempunyai berbagai kendala. Secara garis besar faktor-faktor yang mempengaruhi prestasi belajar siswa dibedakan menjadi tiga, yaitu faktor internal, faktor eksternal, dan faktor pendekatan belajar. Faktor internal meliputi aspek fisiologis (yang bersifat jasmaniah) dan aspek psikologis (yang bersifat rohaniah). Faktor ini berkaitan dengan keadaan diri pribadi peserta didik seperti: motivasi, minat, dan lain-lain (Syah, 2017).

Faktor eksternal meliputi faktor lingkungan sosial (lingkungan sekolah, lingkungan masyarakat, lingkungan keluarga) dan faktor lingkungan nonsosial. Lingkungan keluarga terutama ibu merupakan lingkungan pertama anak bersosialisasi dari anak lahir hingga dewasa. Saefullah (2012: 54) menyatakan bahwa ibu merupakan pendidikan yang pertama dan utama bagi anak, karena pendidikan yang diberikan ibu merupakan pendidikan dasar dan menentukan perkembangan anak selanjutnya. Ibu memiliki kewajiban untuk mengarahkan dan mendidik anaknya agar dapat memiliki perilaku, karakter, dan sikap yang baik. Cara ibu 
mengarahkan anak dalam belajar tentu dapat mempengaruhi keberhasilan pendidikan anak terutama berkaitan dengan pencapaian prestasi belajar yang baik (Sunain, 2017).

Dewantara (1967: 236) mengemukakan bahwa wanita merupakan sosok sentral yang mempengaruhi seluruh sendi-sendi kehidupan di seluruh dunia. Oleh karena itu wanita harus mempunyai komitmen, keyakinan dan jati diri yang kuat agar menjadi salah satu komponen penggerak bangsa. Wanita memiliki kodrat tersendiri yang harus diterima sebagai amanah dari Tuhan Yang Maha Esa. Najib Mahfuz (Inawati, 2014) berpendapat bahwa wanita adalah bagian integral dari keutuhan suatu bangsa (masyarakat) yang memiliki hak dan kewajiban sebagai manusia. Secara fitriyah, wanita adalah manusia yang memiliki martabat kejujuran dan kesetiaan. Pendapat tersebut sesuai dengan kondisi perempuan Indonesia dan tidak hanya dikhususkan pada wanita di daerah tertentu saja. Fitrah seorang perempuan merupakan kelebihan yang perlu untuk digali demi mewujudkan keutuhan suatu bangsa yang menghargai kebudayaannya.

Inawati (2014) mengemukakan bahwa ibu yang memiliki tingkat pendidikan yang baik dan memadai tentunya mempunyai pengetahuan, cara mendidik, dan cara mengarahkan anak berbeda dengan ibu yang memilki tingkat pendidikan tinggi, khususnya dalam mengarahkan anak dalam cara belajar. Ibu yang memiliki tingkat pendidikan yang lebih tinggi dapat memungkinkan untuk lebih percaya diri pada kemampuan yang dimiliki dalam membantu anak belajar di rumah. Namun sayangnya dalam kultur budaya Jawa, sebagaimana tempat penelitian dilaksanakan, ibu merupakan figur orang tua yang biasanya memiliki peran domestik sehingga kurang memperoleh pendidikan yang tinggi. Setinggi apapun pendidikan seorang perempuan, akhirnya akan kembali ke urusan dapur, sumur, dan kasur atau urusan rumah tangga (Inawati, 2014).

Faktor lain yang mempengaruhi siswa dalam mencapai prestasi belajar adalah disiplin belajar. Sukmadinata (2007) menyebutkan bahwa disiplin belajar merupakan salah satu faktor internal. Karakter disiplin bukan sikap moral bawaan dari lahir, melainkan terbentuk dan terpengaruh oleh lingkungannya serta didorong oleh adanya kesadaran dari dalam dirinya. Orang tua terutama ibu dapat menanamkan dan mengembangkan karakter tersebut sejak dari lahir melalui latihan, pendidikan, atau penanaman kebiasaan yang harus dimulai sejak dalam lingkungan keluarga. Slameto (2010) menambahkan bahwa disiplin dalam belajar tidak hanya akan membuat seorang anak memiliki kecakapan mengenai cara belajar yang baik, tetapi juga merupakan suatu proses kearah pembentukan watak yang baik dan pribadi yang luhur. Anak yang memiliki kebiasaan yang baik, maka setiap usaha belajar yang dilakukan akan selalu memberikan hasil yang memuaskan (Milhani, 2017).

Pembelajaran IPS di sekolah menengah pertama di Kota Mungkid, Magelang masih menemukan banyak kendala, diantaranya adalah rendahnya prestasi belajar serta kedisiplinan peserta didik yang belum maksimal. Hal ini tentu disebabkan oleh banyak faktor baik yang 
sifatnya internal maupun eksternal. Faktor internal lebih mengerucut pada aspek psikologis siswa yaitu disiplin belajar, sedangkan faktor eksternal pada mengerucut pada faktor lingkungan sosial yang mempengaruhi siswa khususnya lingkungan keluarga siswa, khususnya ibu. Sebagai orang tua, ibu merupakan faktor terpenting dalam mendidik anak, karena mereka lingkungan pertama anak dalam bersosialisasi dengan lingkungan (Cholifah, dkk., 2016).

Peserta didik SMP Negeri 1 Kota Mungkid belum siap dalam melaksanakan pembelajaran IPS di kelas, hal tersebut terlihat ketika siswa diberikan tugas untuk dikerjakan di rumah mayoritas siswa masih menerapkan sistem kebut semalam dalam mengerjakan tugas bahkan terdapat beberapa siswa yang belum mengerjakan, karena orang tua siswa tidak memberi bimbingan terkait tugas sekolah sehingga dapat diketahui bahwa sebelum dilakukannya pembelajaran di kelas siswa tidak belajar di rumah terlebih dahulu. Mayoritas siswa SMP Negeri 1 Kota Mungkid hanya belajar sebelum diadakan ulangan karena siswa menganggap bahwa mata pelajaran IPS materinya banyak dan selalu menghafal. Oleh karenanya terdapat hubungan antara tingkat pendidikan ibu dan kedisiplinan dalam belajar. Semakin tinggi tingkat pendidikan ibu akan semakin tinggi kedisiplinan dalam belajar. Sementara itu kedisiplinan belajar peserta didik berhubungan dengan prestasi, dimana semakin tinggi kedisplinan dalam belajar semakin tinggi prestasi belajarnya.

\section{Metode Penelitian}

Jenis pendekatan yang digunakan dalam penelitian yaitu kuantitatif jenis expostfacto korelasional. Sukardi (2003: 166) penelitian expostfacto adalah penelitian dimana variabelvariabel bebas telah terjadi ketika penelitian mulai dengan pengamatan variabel terkait dalam suatu penelitian. Dalam penelitian ini akan dicari adakah hubungan antara tingkat Pendidikan ibu (X1) dengan prestasi belajar IPS (Y) dan hubungan antara kedisiplinan belajar peserta didik (X2) dengan prestasi belajar IPS. Gambaran hubungan antar variabel penelitian disajikan dalam Gambar 1 berikut.

Gambar. 1

Hubungan antar variabel penelitian

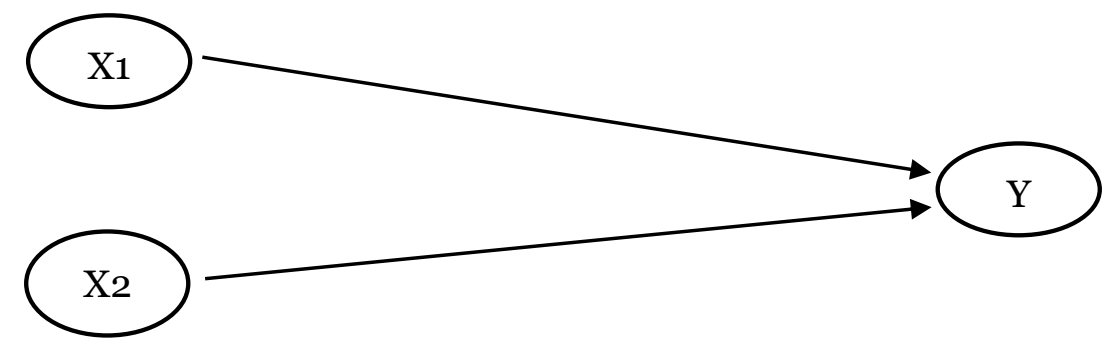


Populasi penelitian peserta didik SMP Negeri 1 Kota Mungkid kelas VII dan VIII yang terdiri dari 12 kelas dengan jumlah seluruh siswa sebanyak 382 siswa. Pemilihan populasi pada SMP Negeri 1 Kota Mungkid didasari oleh pandangan bahwa sekolah tersebut merupakan sekolah favorit yang menjadi barometer kemajuan pendidikan di Kabupaten Magelang sehingga perlu diteliti bagaimanakah keterlibatan orang tua atau wali murid dalam kegiatan pendidikan. Teknik sampling yang digunakan adalah simple random sampling, dimana dengan cara mengundi diperoleh sampel sebanyak 182 siswa.

Adapun teknik pengumpulan data yang digunakan adalah kuesioner/angket yang dalam pelaksanaannya dilakukan melalui daring dengan menggunakan google form. Sedangkan dokumentasi dilakukan untuk memperoleh data penelitian berupa nilai hasil belajar. Dokumen nilai hasil belajar siswa diperoleh dari guru IPS dimana nilai tersebut merupakan hasil penilaian tes sumatif yang dilaksanakan pada tahun ajaran 2019. Pengumpulan data dilaksanakan pada bulan Mei-Juni 2020 dengan cara mengirimkan instrumen melalui aplikasi google form. Teknik analisis data yang dipergunakan adalah teknik korelasi Product Moment dari Karl Pearson yang penghitungannya dilakukan dengan bantuan SPSS versi 16.

\section{Hasil Penelitian dan Pembahasan}

Tingkat pendidikan ibu (X1) yang dimaksudkan dalam penelitian adalah pendidikan formal terakhir yang ditempuh oleh ibu peserta didik, serta memiliki ijazah. Tingkat pendidikan digolongkan ke dalam tiga (3) tingkatan yaitu tinggi (S1-S3), sedang (SMA-D3), dan rendah (SD-SMP). Data diperoleh melalui kuesioner yang diisikan oleh peserta didik menggunakan google form. Data tentang tingkat pendidikan ibu disajikan dalam Tabel 1 di bawah ini.

Tabel 1.

Tingkat Pendidikan Ibu

\begin{tabular}{lcc}
\hline Pendidikan & Frekuensi & Presentase \\
\hline SD & 29 & $15,93 \%$ \\
SMP & 43 & $23,62 \%$ \\
SMA & 80 & $43,95 \%$ \\
Diploma 1 & 3 & $1,64 \%$ \\
Diploma 2 & 0 & $0 \%$ \\
Diploma 3 & 6 & $3,29 \%$ \\
S1 & 20 & $10,98 \%$ \\
S2 & 1 & $0,5 \%$ \\
S3 & 0 & $0 \%$ \\
Jumlah & $\mathbf{1 8 2}$ & $\mathbf{1 0 0 \%}$ \\
\hline
\end{tabular}

Berdasarkan Tabel 1 dapat dilihat bahwa tingkat pendidikan ibu peserta didik SMP Negeri 1 Kota Mungkid Kabupaten Magelang yang termasuk dalam kategori tinggi sebanyak 
sebanyak 21 orang atau 11, 48\%, kategori sedang sebanyak 89 orang atau 48, 90\%, serta kategori rendah sebanyak 71 orang atau $39,1 \%$. Berdasarkan data tersebut dapat diambil kesimpulan bahwa kecenderungan tingkat pendidikan ibu peserta didik kelas VII dan VIII SMP Negeri 1 Kota Mungkid Tahun Ajaran 2019/2020 adalah sedang yaitu berpendidikan SMA-D3 sebesar 48, 90\%. Data tersebut menunjukkan bahwa perubahan sosial dan budaya, gerakan feminisme dan emansipasi wanita telah meningkatkan pendidikan bagi kaum wanita. Sebagian besar orang tua (ibu) peserta didik telah menempuh pendidikan setidaknya SMA bahkan 1 orang telah menempuh pendidikan tinggi hingga program magister.

Berikutnya akan disajikan data variabel disiplin belajar (X2) siswa diukur melalui 25 pernyataan. Hasil analisis data variabel disiplin belajar siswa menunjukkan bahwa skor terendah adalah 55, skor tertinggi 98, diperoleh rata-rata (mean) sebesar 76,98 nilai tengah (median) sebesar 76, modus (mode) sebesar 74, dan standar deviasi sebesar 8,31. Dari hasil distribusi frekuensi skor disiplin belajar siswa kemudian disajikan dalam Tabel 2 sebagai berikut.

Tabel 2.

Kedisiplin Belajar

\begin{tabular}{ccc}
\hline Interval & Frekuensi & Presentase \\
\hline $55-59$ & 1 & $0,5 \%$ \\
$60-64$ & 9 & $4,9 \%$ \\
$65-69$ & 25 & $13,9 \%$ \\
$70-74$ & 42 & $23 \%$ \\
$75-79$ & 40 & $21,9 \%$ \\
$80-84$ & 31 & $17 \%$ \\
$85-89$ & 18 & $9,9 \%$ \\
$90-94$ & 15 & $8,2 \%$ \\
$95-99$ & 1 & $0,5 \%$ \\
Jumlah & $\mathbf{1 8 2}$ & $\mathbf{1 0 0} \%$ \\
\hline
\end{tabular}

Tabel 2 menunjukkan frekuensi kedisiplinan peserta didik dalam belajar tersebesar berada pada interval 70-74, kemudian dari hasil Mean Ideal (Mi) dan Standar Deviasi Ideal (SDi) dapat dilakukan klasifikasi mengenai kecenderungan variabel disiplin belajar siswa yang digolongkan menjadi 4 kategori yaitu sangat tinggi, tinggi, sedang, dan rendah. Tabel 2 menunjukkan bahwa kedisiplinan belajar siswa pada kategori sangat rendah sebanyak o siswa, katergori rendah sebanyak 5 siswa atau 2,8\%, kategori tinggi sebanyak 121 siswa atau 66,4\%, dan kategori sangat tinggi sebanyak 56 siswa atau 30,8\%.

Dari Tabel 2 dapat diketahui bahwa sebagian besar 97, 2\% kecenderungan kedisiplinan belajar peserta didik kelas VII dan VII SMP Kota Mungkid, Kabupaten Magelang tinggi. Hal 
tersebut disebabkan oleh lingkungan belajar yang memadai ketika berada di rumah. Dari instrumen yang dikirimkan kepada responden diketahui bahwa ibu mereka selalu memantau kegiatan belajar putranya, meskipun umumnya mereka tidak bisa mengetahui secara akademis pelajaran IPS SMP. Hasil penghitungan data variabel prestasi belajar IPS diperoleh nilai terendah adalah 40,00, nilai tertinggi 87,00, diperoleh rata-rata (mean) sebesar 67,08 nilai tengah (median) sebesar 69,17, modus (mode) sebesar 70,00, dan standar deviasi sebesar 9,27. Dari hasil distribusi frekuensi skor prestasi belajar IPS kemudian disajikan dalam tabel distribusi sebagai berikut.

Tabel 3 .

Distribusi Frekuensi Prestasi Belajar IPS

\begin{tabular}{lcc}
\hline Interval & Frekuensi & Presentase \\
\hline $40,00-44,99$ & 3 & $1,7 \%$ \\
$45,00-49,99$ & 8 & $4,3 \%$ \\
$50,00-54,99$ & 9 & $5,0 \%$ \\
$55,00-59,99$ & 11 & $6,0 \%$ \\
$60,00-64,99$ & 26 & $14,2 \%$ \\
$65,00-69,99$ & 39 & $21,4 \%$ \\
$70,00-74,99$ & 56 & $30,8 \%$ \\
$75,00-79,99$ & 18 & $9,9 \%$ \\
$80,00-84,99$ & 8 & $4,3 \%$ \\
$85,00-89,99$ & 4 & $2,1 \%$ \\
Jumlah & 182 & $100 \%$ \\
\hline
\end{tabular}

Tabel 3 di atas menunjukkan bahwa frekuensi variabel prestasi belajar IPS paling banyak berada pada interval 70,00-74,99 sebanyak 56 orang (30,8\%), sedangkan frekuensi variabel prestasi belajar IPS paling sedikit pada interval 40,00-44,99 sebanyak 3 orang (1,7\%), Kategori kecenderungan prestasi belajar IPS dalam penelitian ini berdasarkan standar kriteria ketuntasan minimal (KKM) yang ditetapkan di SMP Negeri 1 Kota Mungkid, yaitu 75.oo. Jika nilai siswa $\geq 75.00$ maka dikategorikan tuntas dan jika nilai siswa $<75.00$ maka dikategorikan belum tuntas. Berdasarkan KKM tersebut dapat dibuat tabel distribusi kecenderungan, adapun distribusi kecenderungan variabel prestasi belajar IPS dapat dilihat pada dibawah.

Tabel 4.

Prestasi Belajar IPS

\begin{tabular}{ccc}
\hline Frekuensi & Presentase & Kategori \\
\hline 30 & $16,4 \%$ & Tuntas \\
152 & $83,6 \%$ & Belum Tuntas \\
\hline
\end{tabular}


Tabel distribusi kecenderungan diatas menunjukkan bahwa frekuensi prestasi belajar IPS pada kategori tuntas sebanyak 30 orang $(16,4 \%)$, sedangkan pada kategori belum tuntas sebanyak 152 orang (83,6\%). Frekuensi responden paling banyak dalam variabel prestasi belajar IPS pada kategori belum tuntas yaitu sebanyakk 152 orang. Hal tersebut menunjukkan bahwa mayoritas siswa kelas VII dan VIII SMP Negeri 1 Kota Mungkid memiliki prestasi belajar IPS dibawah KKM. Hal ini tentunya memprihatinkan mengingat ketercapaian kompetensi yang tidak sesuai dengan penetapan yang dilakukan oleh guru IPS. Langkah berikutnya adalah melakukan uji hipotesis dengan teknik yang telah ditentukan sebelumnya.

Pengujian hipotesis pertama dan kedua dilakukan dengan menggunakan teknik korelasi Product Moment (Pearson) yaitu ukuran korelasi linier antara dua variabel kontinum (minimal berskala data interval) yang berdistribusi normal. Adanya asumsi bahwa data harus berdistribusi normal membuat korelasi Product Moment dari Karl Pearson dapat dikatakan sebagai uji parametrik. Dengan bantuan software SPP versi 16 hasil penghitungan uji hipotesis dapat disajikan dalam tabel di bawah.

Tabel 5 .

Ringkasan Hasil Korelasi Product Moment

\begin{tabular}{cccc}
\hline No & Variabel & T hitung & T Tabel \\
\hline 1 & $\mathrm{X} 1-\mathrm{Y}$ & 0,458 & 0,148 \\
2 & $\mathrm{X} 2-\mathrm{Y}$ & 0,383 & 0,148 \\
\hline
\end{tabular}

Dari Tabel 5 dapat dilihat bahwa koefisien korelasi $\left(\mathrm{r}_{\mathrm{xyy}}\right)$ antara variabel tingkat pendidikan ibu (X1) dengan prestasi belajar IPS (Y) sebesar 0,458. Untuk mengetahui hubungan tersebut signifikan atau tidak adalah dengan membandingkan nilai $\mathbf{r}_{\text {hitung }}$ dengan $\mathrm{r}_{\text {tabel }}$ pada taraf signifikansi $5 \%$ dan $\mathrm{N}=182$ sebesar 0,148 . Hasil koefisien korelasi $\left(\mathrm{r}_{\mathrm{xyy}}\right)$ menunjukkan bahwa $r_{\text {hitung }}$ lebih besar dari $r_{\text {tabel }}(0,458>0,148)$ sehingga disimpulkan ada hubungan yang signifikan antara Xi dan Y. Sedangkan koefisien korelasi $\left(\mathrm{r}_{\mathrm{x} 2 \mathrm{y}}\right)$ antara variabel disiplin belajar (X2) dengan prestasi belajar IPS (Y) sebesar 0,383. Untuk mengetahui hubungan tersebut signifikan atau tidak adalah dengan membandingkan nilai $\mathrm{r}_{\text {hitung }}$ dengan $\mathrm{r}_{\text {tabel }}$ pada tarap signifikansi $5 \%$ dan $\mathrm{N}=182$ sebesar 0,148 . Hasil koefisien korelasi $\left(\mathrm{r}_{\mathrm{x} 2 \mathrm{y}}\right)$ menunjukkan bahwa $r_{\text {hitung }}$ lebih besar dari $r_{\text {tabel }}(0,383>0,148)$ maka dapat disimpulkan bahwa terdapat hubungan yang signifikan antara X2 dengan $\mathrm{Y}$.

Untuk menguji apakah X1 dan X2 secara bersama-sama berpengaruh terhadap Y maka digunakan teknik analisis korelasi ganda (Uji F). Teknik tersebut bertujuan untuk mengetahui hubungan kedua variabel bebas dengan terikat secara bersama-sama dan uji signifikansi dengan menggunakan uji F. Uji F dikenal dengan Uji serentak atau uji Model/Uji Anova, 
Hubungan antara tingkat pendidikan ibu ... (Ina Arifa \& Sudrajat)

yaitu uji untuk melihat bagaimanakah pengaruh semua variabel bebasnya secara bersamasama terhadap variabel terikatnya, atau untuk menguji apakah model regresi yang kita buat signifikan atau tidak. Dalam melakukan uji F digunakan software SPP versi 16 dengan hasil uji F dapat dilihat dalam Tabel 6 di bawah.

Tabel 6.

Hasil Analisis Korelasi Ganda uji F

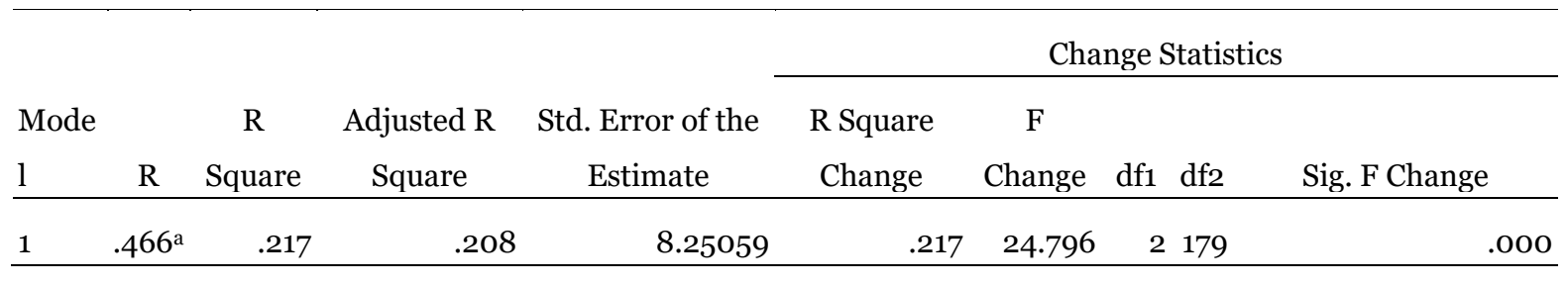

Berdasarkan Tabel 6 di atas, hasil analisis menunjukkan bahwa koefisien korelasi $\left(\mathrm{R}_{\mathrm{y}}\right)$ sebesar 0,466 dengan arah positif. Hal ini berarti terdapat hubungan positif antara tingkat pendidikan ibu (X1) dan disiplin belajar siswa (X2) terhadap prestasi belajar IPS (Y). Pengujian signifikansi digunakan untuk mengetahui signifikansi korelasi tingkat pendidikan ibu (X1) dan disiplin belajar siswa (X2) secara bersama-sama dengan prestasi belajar IPS (Y). Dasar pengambilan keputusan adalah jika $F_{\text {hitung }}$ lebih besar daripada $F_{\text {tabel }}$ pada taraf signifikansi 5\% dan nilai signifikansi lebih kecil dari taraf yang telah ditetapkan, yaitu 0,05 berarti variabel bebas signifikan dengan variabel terikat.

Tabel 7 .

Hasil Analisis Korelasi Ganda untuk Uji F

\begin{tabular}{lccccc}
\hline Model & Sum of Squares & df & Means Square & F & Sig \\
\hline Regression & 3375,901 & 2 & 1687,950 & 24.796 & .000 \\
Residual & 12184.940 & 179 & 68.072 & & \\
Total & 15560.841 & 181 & & & \\
\hline
\end{tabular}

Berdasarkan hasil uji diperoleh nilai F sebesar 24,796 dan nilai signifikansi $F_{\text {hitung }}$ sebesar 0,000. Jika dibandingan dengan nilai $F_{\text {tabel }}$ sebesar 3,05 maka nilai $F_{\text {hitung }}>F_{\text {tabel }}(24,796>$

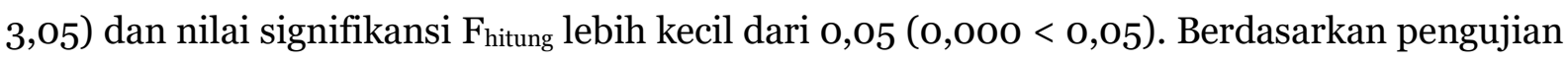
tersebut, dapat disimpulkan bahwa terdapat hubungan positif dan signifikan antara tingkat pendidikan ibu (X1) dan disiplin belajar siswa (X2) secara bersama-sama dengan prestasi belajar IPS (Y) sehingga hipotesis dapat diterima.

Berdasarkan perhitungan dengan analisis Korelasi Product Moment dengan bantuan komputer progam SPSS versi 16, maka dapat disimpulkan bahwa variabel tingkat pendidikan 
ibu dengan prestasi belajar IPS memiliki hubungan positif dan signifikan. Tingkat pendidikan berarti jenjang pendidikan yang ditetapkan berdasarkan pendidikan formal yang telah ditempuh. Tirtahardja dan Sulo (2012: 265) mengemukakan terdapat tiga tingkatan dalam sistem pendidikan di Indonesia, yaitu tingkat pendidikan dasar, pendidikan menengah, dan pendidikan tinggi. Tingkat pendidikan ibu yang lebih tinggi akan memberikan dorongan untuk mencapai prestasi belajar.

Temuan lain dalam penelitian ini menunjukkan bahwa tingkat pendidikan ibu pada kategori tinggi sebanyak 30 orang dengan prestasi belajar IPS tuntas sebanyak 15 orang, kategori menengah sebanyak 80 orang dengan prestasi belajar IPS tuntas sebanyak 15 orang, dan kategori dasar atau rendah terdapat 72 orang dengan prestasi belajar IPS tuntas tidak ada. Mayoritas ibu responden memiliki tingkat pendidikan SMA sebanyak 80 orang (43,95\%), dapat disimpulkan bahwa pendidikan ibu responden dalam penelitian ini sedang atau menengah. Hal tersebut sesuai dengan distribusi kecenderungan bahwa frekuensi terbanyak pada kategori sedang.

Tingkat pendidikan ibu memiliki hubungan positif dengan prestasi belajar IPS, sesuai dengan kerangka berpikir pada penelitian ini bahwa tingkat pendidikan ibu mempengaruhi cara ibu dalam memberikan bimbingan belajar kepada anaknya. Semakin tinggi pengalaman pendidikan, tingkat pendidikan, ilmu pengetahuan yang dimiliki, dan informasi yang diperoleh ibu akan semakin terbuka wawasannya dan akan mudah dapat melakukan peranannya dengan baik, seperti mampu mendidik, membimbing, mengarahkan, mengerti kebutuhan anaknya, memperhatikan perkembangan anak agar dapat berkembang secara optimal baik secara fisik maupun mental. Selain itu, dapat menyadari pentingnya pendidikan bagi masa depan anak sehingga ibu akan menyediakan fasilitas belajar, membantu menyelesaikan kesulitan yang dihadapi anak, memberikan motivasi kepada anak agar dapat semangat dalam belajar, dan membiayai sampai anaknya mencapai pendidikan tinggi (Cholifah, dkk., 2016).

Hasil penelitian membuktikan bahwa terdapat hubungan positif dan signifikan antara disiplin belajar siswa terhadap prestasi belajar IPS kelas VII dan VII SMP Negeri 1 Kota Mungkid, Tahun Ajaran 2019/2020. Hal ini dibuktikan dengan koefisien korelasi $\left(\mathrm{r}_{\mathrm{x} 2 \mathrm{y}}\right)$ antara variabel disiplin belajar siswa (X2) dengan prestasi belajar IPS (Y) adalah o,383 dan $\mathrm{r}_{\text {tabel }}$ dengan $\mathrm{N}=182$ pada taraf signifikansi $5 \%$ sebesar 0,148 . Hal ini menunjukkan bahwa $\mathrm{r}_{\text {hitung }}$ positif dan lebih besar dari $\mathrm{r}_{\text {tabel }}(0,383>0,148)$. Berdasarkan perhitungan dengan analisis Korelasi Product Moment dengan bantuan komputer progam SPSS versi 16, maka dapat disimpulkan bahwa variabel disiplin belajar siswa dengan prestasi belajar IPS memiliki hubungan positif dan signifikan, dengan demikian dapat dikatakan bahwa semakin disiplin siswa maka semakin baik prestasi yang diperoleh. Temuan lain dalam penelitian ini menunjukkan bahwa frekuensi responden paling banyak pada variabel disiplin belajar IPS 
dalam kategori tinggi yaitu sebesar 121 responden 66,4\%. Data tersebut menunjukkan bahwa mayoritas disiplin belajar siswa pada siswa kelas VII dan VIII SMP Negeri 1 Kota Mungkid Tahun Ajaran 2019/2020 dapat dikatakan baik dalam displin waktu dan perbuatan. Mayoritas siswa kelas VII dan VIII SMP Negeri 1 Kota Mungkid telah tepat waktu dalam belajar, seperti saat datang dan pulang sekolah, tidak meninggalkan ataupun membolos saat pelajaran IPS, dapat menyelesaikan tugas sesuai dengan waktu yang sudah ditetapkan, dan mematuhi aturan yang berlaku. Hasil tersebut menunjukkan bahwa peranan ibu dalam mendidik anaknya telah berjalan dengan baik. Kedisiplinan belajar merupakan buah dari pengawasan dan pengendalian yang maksimal dalam keluarga (Inawati, 2014).

Kedisiplinan siswa dalam belajar IPS merupakan salah satu faktor yang mempengaruhi pencapaian prestasi belajar IPS siswa. Siswa yang memiliki disiplin belajar tinggi maka siswa cenderung memiliki prestasi belajar yang tinggi. Hal tersebut sesuai dengan hasil analisis yang menunjukkan bahwa adanya hubungan antara variabel disiplin belajar terhadap prestasi belajar IPS. Saliman (2015: 180) menyatakan bahwa siswa yang dapat mengatur pola belajar secara rutin dan teratur akan mendapatkan prestasi belajar yang memuaskan, baik disiplin belajar di rumah maupun di sekolah. Siswa yang taat pada peraturan, maka juga dapat mengoptimalkan usahanya untuk mendapatkan prestasi belajar yang maksimal.

Hasil analisis hipotesi ketiga menunjukkan terdapat hubungan positif dan signifikan antara tingkat pendidikan ibu dan disiplin belajar siswa terhadap prestasi belajar IPS yang ditunjukkan dengan koefisien korelasi $\left(\mathrm{R}_{\mathrm{y1}, 2}\right)$ sebesar 0,466 dan diperoleh $\mathrm{F}_{\text {hitung }}$ sebesar 24,796 sedangkan $\mathrm{F}_{\text {tabel }}$ pada taraf signifikansi $5 \%$ sebesar 3,05. Hal ini menunjukkan harga $\mathrm{R}_{\mathrm{y} 1,2}$ bernilai positif dan $F_{\text {hitung }}$ lebih besar daripada $F_{\text {tabel }}$ sehingga dapat disimpulkan bahwa memang terdapat hubungan positif dan signifikan antara tingkat pendidikan ibu (X1) dan disiplin belajar siswa (X2) secara bersama-sama dengan prestasi belajar IPS (Y). Hal tersebut sesuai dengan teori bahwa lingkungan keluarga dalam hal ini adalah tingkat pendidikan ibu dan disiplin belajar merupakan faktor yang mempengaruhi prestasi belajar siswa.

Tingkat pendidikan ibu termasuk dalam faktor eksternal, sedangkan disiplin belajar siswa termasuk dalam faktor internal. Analisis juga diperoleh dari nilai R Square sebesar 0,217 yang berarti bahwa 21,7\% variabel tingkat pendidikan ibu dan disiplin belajar siswa secara bersama-sama memiliki hubungan dengan prestasi belajar IPS, sedangkan 78,3\% berhubungan dengan faktor lain yang tidak dianalisis dalam penelitian ini. Temuan lain dalam penelitian ini adalah tingkat pendidikan ibu respondon pada kategori tinggi yang memiliki disiplin kategori tinggi dan prestasi belajar IPS tuntas sebanyak 15 responden dari 30 responden. Berdasarkan data tersebut, diketahui bahwa tingkat pendidikan ibu yang semakin tinggi dan disiplin belajar siswa yang semakin tinggi hanya memiliki hubungan sebesar 21,7\% dengan prestasi belajar belajar IPS, artinya pengaruh antara X1 dan Y masih menjadi sebuah kebetulan, dan tidak semua X1 mempengaruhi Y. 


\section{Simpulan}

Terdapat hubungan positif dan signifikan antara tingkat pendidikan ibu dengan prestasi belajar IPS kelas VII dan VIII SMP Negeri 1 Kota Mungkid Tahun Ajaran 2019/2020. Nilai koefisien korelasi $r_{x 1 y}$ sebesar 0,458 ( $r_{x 1 y}$ sebesar 0,458 $>r_{\text {tabel }} \%$ sebesar 0,148). Semakin tinggi tingkat pendidikan ibu semakin tinggi prestasi belajar peserta didik. Tingkat pendidikan ibu sangat berpengaruh terhadap keberhasilan peserta didik dalam meraih prestasi belajar di sekolah. Dengan pendidikan yang tinggi seorang ibu dapat mengarahkan, mendidik, mengawasi dan memfasilitasi peserta didik dalam kegiatan belajar di rumah. Ibu dapat mendisiplinkan anaknya dalam mengatur dan melaksanakan kegiatan belajar di rumah, apalagi pada masa pandemi Covid 19 dimana pembelajaran dilaksanakan dengan mode daring yang menuntut perhatian dan kontribusi orang tua dalam mendampingi anaknya dalam kegiatan pendidikan khususnya.

Terdapat hubungan positif dan signifikan antara disiplin belajar siswa dengan prestasi belajar IPS kelas VII dan VIII SMP Negeri 1 Kota Mungkid Tahun Ajaran 2019/2020. Hal ini dibuktikan dengan nilai koefisien korelasi $\mathrm{r}_{\mathrm{xyy}}$ sebesar 0,383 $\left(\mathrm{r}_{\mathrm{xxy}}\right.$ sebesar $0,383>\mathrm{r}_{\text {tabel }} 5 \%$ sebesar 0,148). Ada hubungan positif dan signifikan tingkat penddikan ibu dan disiplin belajar siswa secara bersama-sama dengan prestasi belajar IPS kelas VII dan VIII SMP Negeri 1 Kota Mungkid Tahun Ajaran 2019/2020. Ditunjukkan dengan nilai $F_{\text {hitung }}$ sebesar 24,796 dan $F_{\text {tabel }}$

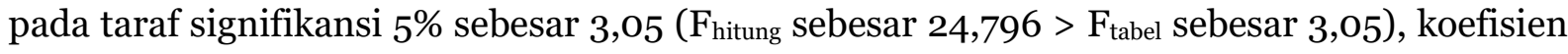
korelasi (R) sebesar 0,466, nilai koefisien determinasi ( $\mathrm{R}^{2}$ ) sebesar 0,217 atau sebesar 21,7\% yang berarti variabel tingkat pendidikan ibu dan disiplin belajar siswa secara bersama-sama memiliki hubungan dengan prestasi belajar IPS sebesar 21,7\%. Temuan lain dalam penelitian ini adalah tingkat pendidikan ibu respondon pada kategori tinggi yang memiliki disiplin kategori tinggi dan prestasi belajar IPS tuntas sebanyak 15 responden dari 30 responden.

Bagi orang tua disarankan agar dapat meningkatkan kedisiplinan anak terutama disiplin dalam belajar, dapat dilakukan dengan cara menerapkan jam belajar pada anak, memantau atau mengawasi kegiatan sekolah anak, memenuhi kebutuhan anak, dan menciptakan suasana belajar yang tentram. Jika orang tua tidak mempunyai waktu untuk menemani anak belajar, akan lebih baik sejak dini anak dibiasakan untuk belajar sehari sekali, karena jika anak yang sejak dini dapat disiplin dlam belajar maka ketika anak tumbuh besar akan terbiasa disiplin dalam belajar. Apabila kedisiplinan anak dalam belajar baik, maka prestasi belajar juga akan meningkat secara signifikan. 
Hubungan antara tingkat pendidikan ibu ... (Ina Arifa \& Sudrajat)

\section{Referensi}

Cholifah, T., N., Degeng, I.N.S., \& Utaya, S. (2016). Pengaruh latar belakang tingkat pendidikan orang tua dan gaya belajar terhadap hasil belajar siswa pada kelas IV SDN Kecamatan Sananwetan Kota Blitar. Jurnal Pendidikan, 1(3) 87-98.

Dewantara, K., H. (1962). Pemikiran Ki Hajar Dewantara. Penerbit Tamansiswa.

Dimyati \& Mujiono. (2013). Belajar dan pembelajaran. PT. Rineka Cipta.

Djamaroh, S., B. (2002). Strategi belajar mengajar. Rineka Cipta.

Hoessein, B. (2000). Prospek resolusi kebijakan dan implementasi otonomi. Elex Computindo.

Inawati, A. (2014). Peran perempuan dalam mempertahankan kebudayaan Jawa dan kearifan lokal, Musawa, 13(2), 195-206.

Milhani, Y. (2017). Keefektifan model pembelajaran students team achievement division dalam pembelajaran IPS di SMP Negeri 15 Yogyakarta, JIPSINDO, 4(2), 101-128. https://doi.org/10.21831/jipsindo.v4i2.17571

Saefullah. (2012). Psikologi perkembangan dan pendidikan. Pustaka Setia.

Saliman. (2015). Bentuk-bentuk kenakalan siswa SMP di Yogyakarta. JIPSINDO, 2(2), 179201. https://doi.org/10.21831/jipsindo.v2i2.7781

Shobri, M. (2017). Strategi meningkatkan mutu pendidikan di Madrasah Aliyah Hasan Jufri, Jurnal Studi Keislaman, 3(1), 56-67.

Slameto. (2010). Belajar dan faktor-faktor yang mempengaruhinya. PT. Rineka Cipta.

Sukardi. (2003). Metodologi penelitian pendidikan: Kompetensi dan praktiknya. Bhumi Aksara.

Sukmadinata \& Syaodih, N. (2007). Landasan psikologi proses pendidikan. PT. Remaja Rosdakarya.

Sunain. (2017). Pengaruh tingkat pendidikan orang tua terhadap tingkat kecerdasan dan keaktifan siswa dari kelas satu sampai dengan kelas enam pada semester 1, Jurnal Pendidikan, 6(2), 47-60.

Supardi \& Widiastuti, A. (2014), Pemanfaatan laboratorium IPS SMP, JIPSINDO, 1(2), 14116o. https://doi.org/10.21831/jipsindo.v2i1.2886

Syah, M. (2017). Psikologi belajar. Rajagrafindo Persada.

Tirtahardja, U., \& Sulo, L. (2012). Pengantar pendidikan. Rineka Cipta.

Toffler, A. (1982). The future shock and the third wave. Bantam Books. 